IZA DP No. 8506

Innovation, Productivity, and Training

Benoit Dostie

September 2014 


\title{
Innovation, Productivity, and Training
}

\author{
Benoit Dostie \\ HEC Montréal \\ and IZA
}

\section{Discussion Paper No. 8506 \\ September 2014}

\author{
IZA \\ P.O. Box 7240 \\ 53072 Bonn \\ Germany \\ Phone: +49-228-3894-0 \\ Fax: +49-228-3894-180 \\ E-mail: iza@iza.org
}

\begin{abstract}
Any opinions expressed here are those of the author(s) and not those of IZA. Research published in this series may include views on policy, but the institute itself takes no institutional policy positions. The IZA research network is committed to the IZA Guiding Principles of Research Integrity.

The Institute for the Study of Labor (IZA) in Bonn is a local and virtual international research center and a place of communication between science, politics and business. IZA is an independent nonprofit organization supported by Deutsche Post Foundation. The center is associated with the University of Bonn and offers a stimulating research environment through its international network, workshops and conferences, data service, project support, research visits and doctoral program. IZA engages in (i) original and internationally competitive research in all fields of labor economics, (ii) development of policy concepts, and (iii) dissemination of research results and concepts to the interested public.
\end{abstract}

IZA Discussion Papers often represent preliminary work and are circulated to encourage discussion. Citation of such a paper should account for its provisional character. A revised version may be available directly from the author. 
IZA Discussion Paper No. 8506

September 2014

\section{ABSTRACT}

\section{Innovation, Productivity, and Training*}

The firm's stock of human capital is an important determinant of its ability to innovate. As such, any increase in this stock through firm-sponsored training might lead to more innovation. We test this hypothesis using detailed data on firms' human capital investments and innovation performance, the Canadian longitudinal linked employer-employee data from 1999-2006. Our results, with workplace fixed-effects and allowing for time-varying productivity shocks, demonstrate that more training leads to more product and process innovation, with on-the-job training playing a role that is as important as classroom training. We then demonstrate that on-the-job training has a positive impact on firm-level productivity through improved process innovation.

JEL Classification: J24, L22, M53, O32

Keywords: innovation, firm-sponsored training, productivity, linked employer-employee data

Corresponding author:

Benoit Dostie

Department of Applied Economics

HEC Montréal

3000, chemin de la Côte-Sainte-Catherine

Montréal (Québec), H3T 2A7

Canada

E-mail: benoit.dostie@hec.ca

\footnotetext{
* We would like to thank Miana Plesca and participants at the Bank of Canada workshop on Labour markets, firms strategies and productivity for comments. The typical caveats apply.
} 


\section{INTRODUCTION}

There are relatively few studies on firm-sponsored training as a determinant of firmlevel innovation performance. This lack of studies is surprising because there are numerous reasons to consider training to be an essential ingredient to successful innovation. ${ }^{1}$ Bauernschuster, Falck, and Heblich (2009) argue that continuous training guarantees access to leading-edge knowledge and thus increase a firm's propensity to innovate. In fact, lack of skill within the enterprise is one of the two most frequently reported obstacles to innovation amongst Canadian firms (Statistics Canada (2012)). ${ }^{2}$ Moreover, because innovation is recognized as having a positive effect on firms' productivity (Crépon, Duguet, and Mairesse (1998)), it is possible that the link between training and productivity is partly through innovation.

Bauernschuster, Falck, and Heblich (2009) provide the most convincing results of the positive impact of firm-sponsored training on innovation. These authors find that such training has a positive and statistically significant impact on innovation in German firms over the 1997-2001 period. Their results demonstrate that a 10 percentage-point increase in training intensity translates into a 10 percentage-point higher propensity to innovate. Distinguishing between routine and radical innovation, they find that training only has an impact on the former. They hypothesize that radical innovation is more difficult to achieve because it depends on the intrinsic abilities of the workforce such as creativity, inventive talent and the desire to work in teams. Moreover, with radical innovation being deemed as overly risky, firms might favor training for routine innovation to keep abreast of technological progress.

More recently, Gonzàlez, Miles-Touya, and Pazò (2012) employ a panel of approximately 10,000 Spanish manufacturing firms over the period 2001-2006 and find that worker training has a significant effect on firm innovation performance and that it also complements R\&D. Utilizing a panel of nearly 1,000 French firms from 1986-1992, Gallié and Legros (2012) find significant effects of R\&D intensity and training on patenting activities (see also Legros and Galia (2012)). ${ }^{3}$

This first set of empirical results concerning the relationship between training and innovation is interesting but suffers from two important shortcomings. First, these

\footnotetext{
${ }^{1}$ Other ingredients include investments in the right capital equipment, an R\&D program if needed; and retention of consultants and various external suppliers, including licensing arrangements and partnerships with other firms (The Expert Panel on Business Innovation (2009)).

${ }^{2}$ The most frequently cited obstacle was 'Uncertainty and risk' and the third most frequent obstacle was 'Internal financing'.

${ }^{3}$ The link between training and innovation has also been examined in the management literature, see for example Beugelsdijk (2008).
} 
studies do not distinguish between different types of training, with the most important distinction being between classroom (formal) and on-the-job (informal) training. It is well known that these two types of training have different impacts on productivity (Dostie (2013), Zwick (2005), Barrett and O'Connell (2001), Black and Lynch (1996)). Many studies also note that the amount of on-the-job training offered by firms can be much greater than the amount of classroom training (Pischke (2005)) and thus may have a larger impact on a firm's propensity to innovate.

Second, it is also important to distinguish between different types of innovation. Becheikh, Landry, and Amara (2006), and Michie and Sheehan (2003) note that different types of innovation require different types of inputs. This is the case, for example, with respect to the processes that lead to product innovation and procedural innovation.

In the current paper, we employ longitudinal linked employer-employee Canadian establishment-level data from the Workplace and Employee Survey 1999-2006 to study the links between firm-sponsored training, innovation and productivity. The data contain detailed information on the number of employees receiving classroom and onthe-job training, and four firm-level measures of innovation. For each firm, we have information on whether the firm conducted product and/or process innovation, and whether the innovation was routine or radical.

We take advantage of the longitudinal structure of the data in the statistical model to include workplace-level fixed-effects. Furthermore, we employ IV estimation methods to take into account unobserved workplace-level heterogeneity and obtain estimates of the impact of firm-sponsored training that are robust to the presence of time-varying sources of endogeneity.

We also utilize additional information on workplace-level productivity as measured by sales per employee to disentangle the impact of training on productivity and innovation. Doing so, we contribute to the relatively young literature using the regression approach to estimate the relationship between productivity and innovation. This literature is still in its relative infancy due to the lack of appropriate data (Hall (2011)).

Of note, in this context, it is important to distinguish between product and process innovation. In particular, Hall (2011) surveys the evidence and concludes that there are substantial positive impacts of product innovation on revenue productivity but that the impact of process innovation is more ambiguous, suggesting some market power on the part of the firms being analyzed.

To distinguish the impact of training on innovation from its impact on productivity, we employ a model that is related to that introduced by Crépon, Duguet, and 
Mairesse (1998). Their model captures the idea that productivity growth is the dividend produced by innovation (Lynch and Sheikh (2011)). However, we account for possible selectivity and simultaneity biases in our recursive nonlinear system by taking advantage of the longitudinal structure of the data using a within-3SLS estimator as suggested by Baltagi (2013).

We find that both classroom and on-the-job training have a positive impact on workplace-level innovation performance. In fact, for many types of innovation, on-thejob training has a greater impact than classroom training. This result is surprising because when estimating the impact of firm-sponsored training on productivity, the opposite results hold true. It is typically found that classroom training has a much larger impact on productivity than on-the-job training.

We also find that the improved process innovation is the type of innovation that has the largest impact on firm-level productivity. Taken together with the previous results that on-the-job training is an important driver behind improved process innovation, we conclude that on-the-job training can increase productivity through improved process innovation.

\section{DATA}

We employ 1999-2006 data from the Workplace and Employee Survey (WES) conducted by Statistics Canada. ${ }^{4}$ The survey is both longitudinal and linked in that it documents the characteristics of workers and workplaces over time. Abowd and Kramarz (1999) classify WES as a survey in which both the sample of workplaces and the sample of workers are cross-sectionally representative of the target population.

The structure of the survey is summarized in Table 1. The initial 1999 workplace sample is followed over time and is supplemented at two-year intervals with a sample of births that are selected from units added to the Business Register since the last survey occasion. ${ }^{5}$ The response rates for each cross-section are typically over 90 percent. ${ }^{6}$

To compute training intensities, we employ information on the proportion of employees who received on-the-job training and the proportion of employees who received classroom training (in both cases related to their job) in the past year (as of March

\footnotetext{
${ }^{4}$ This is a restricted-access data set that is available in the Statistics Canada network of Research Data Centers (RDC). Remote access is also possible.

${ }^{5}$ In 1999, workplace data were collected in person. Subsequent workplace surveys were conducted by means of computer-assisted telephone interviews.

${ }^{6}$ In the case of total non-response, respondents are withdrawn entirely from the survey and sampling weights are recalculated to preserve representativeness of the sample.
} 
31st). ${ }^{7}$ The survey defines classroom training in a detailed fashion and indicates that all training activities should have the following:

- a pre-determined format, including a pre-defined objective;

- specific content;

- progress that may be monitored and/or evaluated.

However, on-the-job training is only defined as being informal.

With respect to innovation performance, the WES contains four measures at the workplace level. In each case, the question refers to whether the workplace introduced a specific type of innovation in the last year. There is no information on the extent or intensity of the innovation. ${ }^{8}$ The four types of innovation are as follows:

(1) new products or services,

(2) improved products or services,

(3) new processes,

(4) improved processes.

As defined by Statistics Canada, new products or services differ significantly in character or intended use from previously goods or services whereas improved products are those whose performance has been significantly enhanced or upgraded. New processes include the adoption of new methods of goods production or service delivery whereas improved processes are those whose performance has been significantly enhanced or upgraded. ${ }^{9}$

These definitions closely follow those of The Oslo Manual (Organization for Economic Co-operation and Development (OECD) (2005)) in which production innovation is defined as follows: "A product innovation is the introduction of a good or service that is new or significantly improved with respect to its characteristics or intended uses. This includes significant improvements in technical specifications, components and materials, incorporated software, user friendliness or other functional characteristics." A process innovation is the "implementation of a new or significantly improved production or delivery method. This includes significant changes in techniques, equipment and/or software."

\footnotetext{
${ }_{7}$ This measure includes full-time, part-time, permanent and temporary employees

${ }^{8}$ For product innovation, an interesting measure is the share of sales that is due to the new product. For process innovation, one could use the extent of cost reduction brought by the innovation.

${ }^{9}$ The survey does not distinguish between new to the market and new to the firm. The interpretation is left to the respondent. The survey did not include information about marketing or organizational innovation in its innovation component.
} 
Table 2 presents the incidence of each type of innovation per year. Caution must be used in interpreting averages in even years because of the sampling process. Although there are many variations on a year-to-year basis, these summary statistics demonstrate that product innovation is more likely that process innovation. Additionally, improvements in processes or products are more likely than new products or processes, most likely because the former are more difficult to achieve.

\section{TRAining AND InNOVATION}

In Table 3, we present the incidence of each type of innovation conditional on whether the workplace offers classroom or on-the-job training. The table demonstrates that workplaces that offer training are much more likely to innovate. The rates of innovation for workplaces that offer classroom training are on average twice as high as those of workplaces that do not. For example, 39\% of workplaces that offered classroom training introduced product innovation whereas only $22 \%$ of workplaces that did not offer classroom training introduced such innovation. The comparison is even more striking for the introduction of new processes, i.e. $31 \%$ versus $13 \%$. The impact of on-the-job training seems to be as strong.

Table 4 presents average training intensities for innovating workplaces compared to workplaces that do not innovate. Classroom and on-the-job training intensities are again on average twice as high in innovating workplaces, with a greater difference in the case of process innovation. For example, the average proportion of employees who undertook on-the-job training in workplaces that innovated with new products was $42 \%$, compared to $24 \%$ in workplaces that did not.

It remains to be seen whether this relationship between training and innovation holds when taking into account other determinants of innovation performance and confounding influences. There are reasons to consider that this is the case, as the positive relationship between training and innovation has been commented upon in several studies using early waves of the WES. Zeytinoglu and Cooke (2009) utilize the 2001 version of the WES and their multivariate results demonstrate that innovation that is introduced in the workplace is significantly associated with providing on-the-job training. Walsworth and Verma (2007) use years 1999-2002 from the WES and find that autonomy training has a positive relationship with innovation. ${ }^{10}$

To study the impact of training on innovation performance, we first estimate a linear probability model in which Innovation at workplace $j$ at time $t$ is determined by the

\footnotetext{
${ }^{10}$ Baldwin and Johnson (1995) also find a strong association between training and innovation in a survey of small and medium-sized Canadian firms.
} 
proportion of workers who undertook classroom $(\mathrm{cls})$ or on-the-job (otj) training in the past year:

$$
\text { Innovation }_{j t}=\alpha+\rho_{\text {cls }} \text { Training }_{j t}^{\text {cls }}+\rho_{\text {otj }} \text { Training }_{j t}^{\text {otj }}+\beta X_{j t}+\epsilon_{j t}
$$

Other determinants of innovation performance included in $X_{j t}$ are workforce characteristics such as the proportion of employees using a computer, the proportion of employees covered by a collective bargaining agreement (CBA) and the proportion of managers. We also include firm size (to account for unrecoverable costs of R\&D), industry and year dummies. $\epsilon$ is the error term.

Table 5 presents the coefficients that were estimates obtained by ordinary least squares. Of note, the standard errors for all of the coefficient estimates are bootstrapped to fully account for the stratified sampling procedure utilized for collecting the data (Statistics Canada (2004)).

The results demonstrate that a workplace that moves from training no employees to training all of its employees will experience an increase in its probability of innovation ranging from 12.5 to 19.1 probability points. Interestingly, on-the-job training seems to have a greater impact on innovation than classroom training. This result is surprising because, in the case of firm-level productivity performance, previous research find that classroom training has a greater impact on productivity (Dostie (2013), Zwick (2005), Barrett and O'Connell (2001), Black and Lynch (1996)).

Turning to other determinants of innovation, we also find that increasing computer use raises productivity. In addition, both the proportion of employees covered by a CBA and the proportion of managers seem to have a positive impact on introducing new product innovations but not on other types of innovation. We also obtain the well-known result that large firms have better innovation performance. ${ }^{11}$

\section{INNOVATION, TURNOVER AND COMPETITIVE PRESSURES}

Stoyanov and Zubanov (2012) recently argue that worker mobility drives innovation performance through knowledge spillovers. Because on-the-job training is more closely related to turnover (Dostie (2013)), one source of concern with respect to the previous results is that on-the-job training is spuriously correlated with innovation because of worker mobility.

\footnotetext{
${ }^{11}$ This could reflect the fact that there are irrecoverable costs of $R \& D$ that are better supported by larger firms or that large workplaces are involved in a greater number of activities and are more likely to have an innovation in at least one of them (Hall (2011)).
} 
Fortunately, we are able to address this concern because the WES contains detailed information about the workplace's workforce flows in the previous year. For example, to construct the inflow rate, we have information on the total number of new hires in the last year from the workplace questionnaire and divide by the total number of employees at this workplace. To construct the outflow rate, we first compute the total number of workers who separated from the firm in the past year. Separations can be due to resignations, permanent layoffs, dismissal for cause, or retirement. We then divide by the total number of employees as of March 31st of the current year.

Table 6 demonstrates that the estimated impact of firm-sponsored training on innovation remains nearly unchanged when taking into account turnover. The coefficients for the intensity of classroom and on-the-job training are nearly identical to those presented in Section 3. It is interesting to note that the inflow rate is positively correlated with all four types of innovation. This result supports the hypothesis that new workers are a source of new knowledge. Outflow rates, by contrast, are negatively correlated with innovation.

An additional focus of the innovation literature is on how competitive pressures affect incentives to innovate. A seminal reference on this particular topic is Aghion, Bloom, Blundell, Griffith, and Howitt (2005) who find that the relationship between competition and innovation takes an inverted-U form. More recently, Spulber (2013) find that competitive pressures have a positive impact on firm-level innovation performance when intellectual property laws create a market for innovation. Because competitive pressures might also affect training intensities in a variety of ways (Brunello and De Paola (2008)), it seems important to take them into account as determinants of innovation.

We are fortunate that the WES contains information on the competitive pressures that workplaces face. More specifically, it provides details concerning whether workplaces directly compete with locally, Canadian or internationally owned firms. The survey then indicates how many firms (whether based in Canada or not) offer products / services that directly competing with theirs in their most important market. Based on the answers to these questions, we build three additional dichotomous variables, indicating whether the number of direct competitors is 0,1 to 5,6 to 20 , or over 20 .

The coefficient estimates in the last panel of Table 6 demonstrate a statistically significant and positive impact of the number of competitors on the propensity to innovate. The impact is stronger in the case of product/service improvements and is stronger for a number of competitors between 6 and 20, becoming weaker for higher numbers of competitors. Thus, the relationship between innovation and the number of competitors seems to exhibit an inverse- $U$ shaped relationship, similar to Aghion, 
Bloom, Blundell, Griffith, and Howitt (2005). However, taking into account competitive pressures does not weaken the relationship between firm-sponsored training and innovation. The estimated coefficients for training intensities remain nearly identical to those of Table 5 .

\section{UNOBSERVED WORKPLACE HETEROGENEITY AND TIME-VARYING PRODUCTIVITY SHOCKS}

In attempting to estimate the causal impact of firm-sponsored training on innovation, we are primarily concerned with two additional sources of possible bias. These sources of bias might lead to simultaneity between firm-sponsored training and innovation. Furthermore, firm-level innovation in itself can lead to or require firm-sponsored training, e.g. a firm that introduces new software must train its workforce on how to employ it. Our focus here is only in disentangling one part of this complex relationship, i.e. how firm-sponsored training affects innovation performance.

The first source of bias is unobserved workplace-level heterogeneity $\left(\psi_{j}\right)$ in

$$
\text { Innovation }_{j t}=\alpha+\rho_{c l s} \text { Training }_{j t}^{\text {cls }}+\rho_{\text {otj }} \text { Training }_{j t}^{\text {otj }}+\beta X_{j t}+\psi_{j}+\varepsilon_{j t}
$$

with $\epsilon_{j t}$ from equation (3.1) defined as

$$
\epsilon_{j t}=\psi_{j}+\varepsilon_{j t}
$$

If $\psi_{j}$ contains workplace-level characteristics that are correlated with both training decisions and innovation performance, this will introduce biases in our previous coefficients. For example, if high-ability managers can introduce more innovations and also invest more in training, the real impact of training will be lower than previously estimated.

Table 7 presents coefficient estimates from equation (5.1) that include workplacelevel fixed effects. The results demonstrate sizable and statistically significant impacts of both classroom and on-the-job training intensities on innovation performance. Increases in innovation probabilities, albeit lower than previously estimated, range from 6.6 to 11.2 probability points. Except in the case of new product innovation, on-the-job training has the greater impact on innovation performance.

The second source of bias might come from unobserved productivity shocks $\left(\eta_{j t}\right)$. In this case, we let

$$
\epsilon_{j t}=\psi_{j}+\eta_{j t}+\varepsilon_{j t} .
$$


One interpretation of these shocks is that demand shocks lead to fewer financial resources in the workplace. They might lead to fewer training investments and less R\&D and thus less innovation performance.

To address such shocks, we take advantage of the longitudinal nature of WES. We first assume that $\eta_{j t}$ follows an autoregressive process of order 1:

$$
\eta_{j t}=\alpha \eta_{j t-1}+e_{j t}
$$

with $e_{j t}$ as the residual error term. ${ }^{12}$

Equation (3.1) with the error term defined as in equation (5.3) then becomes

$$
\begin{aligned}
\text { Innovation }_{j t}= & \alpha \text { Innovation }_{j t-1}+ \\
& +\rho_{\text {cls }} \text { Training }_{j t}^{c l s}-\alpha \rho_{\text {cls }} \text { Training }_{j t-1}^{c l s}+ \\
& +\rho_{\text {otj }} \text { Training }_{j t}^{\text {ot }}-\alpha \rho_{\text {otj }} \text { Training }_{j t-1}^{\text {ot }}+ \\
& +\beta X_{j t}-\alpha \beta X_{j t-1} \\
& +\left(\psi_{j}(1-\alpha)+e_{j t}+\eta_{j t}-\alpha \eta_{j t-1}\right) .
\end{aligned}
$$

Defining $\psi_{j}^{*}=\psi_{j}-\alpha \psi_{j}$ and $\eta_{j t}^{*}=\eta_{j t}-\alpha \eta_{j t-1}+e_{j t}$ yields

$$
\begin{aligned}
\text { Innovation }_{j t}= & \pi_{1} \text { Innovation }_{j t-1}+ \\
& +\pi_{2} \text { Training }_{j t}^{\text {cls }}+\pi_{3} \text { Training }_{j t-1}^{c l s}+ \\
& +\pi_{4} \text { Training }_{j t}^{\text {ot }}+\pi_{5} \text { Training }_{j t-1}^{\text {otj }}+ \\
& +\pi_{6} X_{j t}+\pi_{7} X_{j t-1} \\
& +\psi_{j}^{*}+\eta_{j t}^{*},
\end{aligned}
$$

subject to:

$$
\begin{aligned}
& \pi_{3}=-\pi_{2} \pi_{1} \\
& \pi_{5}=-\pi_{4} \pi_{1} \\
& \pi_{7}=-\pi_{6} \pi_{1}
\end{aligned}
$$

As described by Blundell and Bond (2000), even in the presence of endogeneity, it is possible to obtain consistent estimates for the parameters in (5.6) by using GMM methods. The Blundell and Bond (2000) estimator utilizes the usual moment restrictions:

$$
E\left[Z_{j t-s} \triangle \eta_{j t}^{*}\right]=0
$$

\footnotetext{
${ }^{12}$ This assumption will be formally tested later.
} 
where $Z_{j t-s}=\left(\right.$ Innovation $_{j t-s}$, Training $_{j t-s}^{\text {cls }}$, Training $\left._{j t-s}^{\text {otj }}, X_{j t-s}\right)$ and $s \geq 3$. Briefly described, the method involves taking the first-difference to exclude workplace fixed effects and then estimating the resulting equation utilizing suitably chosen lagged levels of the explanatory variables as instruments. Given consistent estimates of $\pi$ and $\operatorname{var}(\pi)$, we finally recover parameter estimates for the structural parameter $\left(\rho_{c l s}, \rho_{\text {otj }}, \beta, \alpha\right)$ by imposing common factor restrictions and using minimum distance.

In estimating (5.6), we employ lags from 3 on back to create the GMM-type instruments (as described in Arellano and Bond (1991)). We utilize first differences of all the exogenous variables as standard instruments. As a specification check, we compute the Sargan test of over-identifying restriction for the one-step system estimator. In this case, we cannot reject the null hypothesis that the over-identifying restrictions are valid.

Table 8 presents the results from estimating the innovation equation taking into account both unobserved workplace heterogeneity and time-varying unobserved productivity shocks. The coefficient estimates are slightly lower than previous FE estimates but present both classroom and on-the-job firm-sponsored training as having a statistically significant impact on innovation performance. The estimated coefficients are similar to the previous fixed effects estimates for most types of innovation. This result can be interpreted as demonstrating that biases due to unobserved workplace heterogeneity are much more important to take into account than those due to unobserved productivity shocks.

Compared to the previous results, the coefficients for on-the-job training are much closer to those of classroom training. Taken at face value, classroom training has a slightly larger impact on improved process or improved product innovations, and on-the-job training has a slightly larger impact on new product or new processe innovations. It is interesting to note that on-the-job training has a larger impact on more radical innovation. However, we cannot reject the null hypothesis that both types of training have a similar effect on all types of innovation.

Compared to its impact on productivity, on-the-job training has a significant impact on innovation. However, it is well known that innovation and productivity are closely linked. We attempt to disentangle these two seemingly contradictory results in Section 7.

\section{WORKFORCE CHARACTERISTICS}

Although our previous specification includes many workforce characteristics as determinants of innovation, it has one (glaring) omission, i.e. formal education. Crépon, 
Duguet, and Mairesse (1998)'s theoretical model of innovation emphasizes the role of knowledge capital. Moreover, model of endogenous growth such as those described in Aghion and Howitt (2009) typically place a greater emphasis on education than firmsponsored training. Recent empirical evidence also points toward tertiary education as having a more meaningful impact on innovation than less advanced degrees (Aghion, Boustan, Hoxby, and Vandenbussche (2009)). ${ }^{13}$

Although it can be argued that the stock of human capital is fixed in the short term and can be taken into account utilizing workplace fixed effects, it is interesting to contrast its role as a determinant of innovation compared to firm-sponsored training. To assess the role of knowledge capital, we utilize the linked employer-employee data to construct measures of the stock of human capital of the firm as proxied by the education of its workforce, employing the information on education contained in the employee portion of the survey.

For the employee component of the survey, the target population is the collection of all employees working, or on paid leave, in the workplace target population. Employees are sampled from an employee list that the selected workplaces provided. For every workplace, a maximum number of 24 employees is selected, and for establishments with less than 4 employees, all employees are sampled.

We obtain a sample of 30,563 workplaces, for which we construct the proportion of employees in each of 13 possible education groups. The total number of workplaces is lower than that in the previous sample both because of employee non-responses and because no employees were sampled in 2006.

Because not all workers are sampled in every workplace, it is not possible to separately use 13 different education groups. For our measure of the workplace's stock of human capital, we use the proportion of its employees with some postsecondary education. Workers with trade or vocational diplomas, workers with some or completed college, CEGEP or institute of technology, workers with some or completed university, and workers with degrees above a bachelor's degree are included in this proportion.

In this econometric specification, we also include a more detailed description of the occupational structure of the workplace. In addition to the proportion of managers, we include the proportion in the following occupational groups: professionals, marketing/sales, clerical/administrative, technical/trades, production and others.

\footnotetext{
${ }^{13}$ For Canada, early evidence from Rao, Tang, and Wang (2002) demonstrates that firms that hire experienced employees and new graduates from universities outperform the firms that do not in terms of both product and process innovation. Parrotta, Pozzoli, and Pytlikova (2014)'s recent evidence from Denmark demonstrates that firms with higher shares of highly skilled and vocational workers have higher propensities to patent.
} 
Table 9 presents results obtained adding these measures of human capital. Altough formal education is viewed as having a positive impact on the workplace's innovation propensity, the impact of training remains significant and important. These results are coherent with a view of the workplace in which human capital that is acquired through formal education depreciates more quickly because of rapid technological progress. Firm-sponsored training is viewed as crucial for maintaining and disseminating the cutting-edge knowledge that is necessary for innovation.

The results for the different occupational groups are interesting on their own. Whereas the proportion of managers has a more consistent impact on all four types of innovation, the proportion of employees in sales and marketing has a significant impact only in the case of product innovation. The proportions of workers who are professionals or in the technical/trade occupation also have a positive and significant impact on all types of innovation except improved processes. ${ }^{14}$

\section{TRAining, PRODUCTIVITY AND INNOVATION}

To distinguish the impact of training on innovation from its impact on productivity, we utilize a model that is related to that elaborated by Crépon, Duguet, and Mairesse (1998), in which innovation explains productivity. Because we have no information on the amounts spent on R\&D, our model has only two equations. The first equation explains firm-level innovation performance as described previously. ${ }^{15}$

The second equation takes as inputs innovation and training intensities to explain variations in workplace productivity. As explained by Hall (2011), innovation can increase efficiency and improve the goods and services that firms offer, thus increasing demand and reducing the costs of production. When estimating the impact of innovation on productivity, the measures of innovation that are typically used include amount spent on R\&D, the number of patents the workplace applied for or, more recently, the percentage of sales coming from products less than five years old. ${ }^{16}$ However, it is possible that R\&D activity does not yield an innovation and might even have a negative impact on productivity. Using actual innovation performance as a determinant of

\footnotetext{
${ }^{14}$ Crépon, Duguet, and Mairesse (1998) found a positive impact for firms with more engineers and firms with more managers.

${ }^{15}$ We do not allow for any feedback from productivity to innovation.

${ }^{16}$ Using sales from recent products has the advantage of taking into account product improvements (Mairesse, Crépon, and Duguet (2000)).
} 
productivity takes into account that innovation output rather than innovation output determines productivity. ${ }^{17}$

Our basic model for the productivity equation is a Cobb-Douglas production function where the dependent variable is workplace value added:

$$
\ln Q_{j t}=\beta_{L} \ln L^{E}{ }_{j t}+\sum_{k=1}^{4} \delta_{k} \text { Innov }_{k}+\gamma Z_{j t}+\epsilon_{j t} .
$$

$L_{j t}^{E}$ is a measure of effective labor. This measure depends on the number of employees who received training $\left(\left(L^{T}\right)\right)$ and the number of employees who did not receive any training $\left(\left(L^{N T}\right)\right)$. Formally, it is defined as

$$
\begin{aligned}
L_{j t}^{E} & =\lambda_{T} L_{j t}^{T}+\lambda_{N T} L_{j t}^{N T} \\
& =\lambda_{N T} L_{j t}+\left(\lambda_{T}-\lambda_{N T}\right) L_{j t}^{T}
\end{aligned}
$$

where $L$ is the total number of employees. $\lambda_{T}$ (and $\lambda_{N T}$ ) are load factors that convert the number of employees who received (and did not receive) training into effective labor. By taking the natural $\log$ on each side of equation 7.2 , we can approximate $L_{j t}^{E}$ by

$$
\ln L_{j t}^{E} \approx \ln \lambda_{N T}+\ln L_{j t}+\ln \left(1+\left(\frac{\lambda_{T}}{\lambda_{N T}}-1\right) P_{j t}\right)
$$

where $P_{j t}$ is defined as the proportion of employees who received training. ${ }^{18}$

Innov $_{k}$ with $k=1, \ldots, 4$ represents the four possible types of innovation and $\delta_{k}$ represents the percentage change in productivity in a firm experiencing innovation of type $k$.

By allowing all four types of innovation to have distinct impacts on productivity, we can verify whether Hall (2011)'s theoretical model's implications that there should be positive impacts of product innovation on revenue productivity holds with our data. We note that her model yields that the impact of process of innovation is more ambiguous.

One possible drawback of including all four types of innovation is if this introduces multicollinearity in the econometric model. We find this not to be a problem, in part because of our large sample size. Also, while all four types of innovation are positively correlated, correlations are not too large and range from 0.44 for the correlation between new products and improved processes to 0.71 for the correlation between new and

\footnotetext{
${ }^{17}$ Ballot, Fakhfakh, and Taymaz (2001) also consider that increases in human capital have an impact on productivity through innovation although they do not model the intermediate innovation step.

${ }^{18}$ The approximation is correct as long as $\frac{L^{T}}{L}\left(\frac{\lambda_{T}}{\lambda_{N T}}-1\right)$ is close to zero.
} 
improved processes. The second highest correlation (0.61) is between new and improved products.

Finally, $Z_{j t}$ includes controls for industry and year, and $\epsilon_{j t}$ is a residual error term. As is common with this type of representative firm-level data, capital stocks for each firm are not available. We treat the capital stock as an omitted variable that is included in $\epsilon_{j t}$ and that might be correlated with training decisions. Thus we employ an estimation method for our joint model that is designed to estimate the causal impact of training and innovation on productivity that is robust to this omitted variable.

Substituting equation (7.3) in (7.1), we obtain

$$
\ln Q_{j t} \approx \beta_{0}+\beta_{L} \ln L_{j t}+\beta_{L} \kappa P_{j t}++\sum_{k=1}^{4} \delta_{k} \text { Innov }_{k}+\gamma Z_{j t}+\epsilon_{j t}
$$

where $\kappa=\left(\frac{\lambda_{T}}{\lambda_{N T}}-1\right)$ is interpreted as the relative productivity of an employee who received training compared to an employee who did not.

Column 1 of Table 10 presents reduced form estimates of estimating equation 7.1, including the four types of innovation. Only improved process innovation appears to have an impact on concurrent productivity performance. ${ }^{19}$ The coefficient estimates imply that process innovation leads to gains in productivity on the order of $8-10 \%{ }^{20}$

Although few studies in this literature allow for dynamic responses, we employ the longitudinal structure of our data to perform additional exploratory analysis. ${ }^{21}$ Columns 2 and 3 allow for a lagged impact of innovation on productivity in period $t-1$ and $t-2$ respectively.

Our previous conclusion does not change. In each specification, only improved process innovation has a statistically significant impact on productivity. In addition, we continue to predominantly find no impact of product innovation on productivity. The impact is even negative in some specifications. One interpretation is that, in our sample (i.e. primarily small and medium-sized firms in the service sector), firms modify or introduce new products in response to declines in the demand for existing products and that following improvements in productivity occur (if they occur) even further in time.

\footnotetext{
${ }^{19}$ If we construct aggregate measures for product and process innovation, only the later is found to have an impact on productivity.

${ }^{20}$ Hall (2011) reports that for manufacturing sectors in Western Europe, typical estimates imply that product innovating firms have an average productivity that is approximately 8 percent higher than non-innovators, but there is a wide dispersion. See Mohnen and Hall (2013) for a complete overview of the empirical literature.

${ }^{21}$ Of the 25 empirical studies of the relationship between innovation and productivity reviewed by Hall (2011), 22 are cross-sectional in nature.
} 
It is interesting to note that the coefficients for improved process innovation are pretty similar regardless of the time period. A workplace that innovates by improving processes is $10 \%$ more productive than a workplace that does not improve its processes. Because of the role of improved process innovation, we focus on this particular type of innovation in the joint analysis that follows.

To build our model to identify the impact of innovation and training on productivity, let

$$
\epsilon_{j t}=\zeta_{j}+e_{j t}
$$

with $\zeta_{j}$ representing workplace unobserved heterogeneity.

We estimate this productivity equation simultaneously with innovation equation as determined by (5.1). Taken together, the innovation and productivity equations form a recursive nonlinear system. However, our estimation strategy takes the longitudinal structure of the data into account for possible selectivity and simultaneity biases due to fixed-over time unobserved workplace specific characteristics (or other omitted variables). ${ }^{22}$

We eliminate workplace-specific fixed effects by recasting both the productivity and innovation equations in deviations from their respective means. We then obtain the 3SLS estimator utilizing the appropriate weighting matrix, effectively computing the within-3SLS estimator (Baltagi (2013)).

Let the system of equations given by equations (5.1) and (7.4) be summarized by

$$
y=Z \delta+u
$$

with

$$
\Omega=E\left[u u^{\prime}\right] .
$$

Workplace fixed-effects dissapear when pre-multiplying the system by $\left(I_{2} \otimes Q\right)$ with $Q=I_{N T}-P$ and $P=I_{N} \otimes J_{T}$ where $J_{T}$ is a matrix of ones of dimension $T$, yielding the new system:

$$
\tilde{y}=\tilde{Z} \delta+\tilde{u} .
$$

The within-3SLS estimator is then defined as

$$
\tilde{\delta}_{W 3 S L S}=\left[\tilde{Z} \tilde{\Omega}^{-1} \tilde{Z}\right]^{-1}\left[\tilde{Z} \tilde{\Omega}^{-1} \tilde{y}\right]
$$

in which we take $\tilde{X}=Q X$ and $\left(I_{2} \otimes \tilde{X}\right)$ as the set of instruments, and $\tilde{\Omega}=E\left[\tilde{u} \tilde{u}^{\prime}\right]$.

\footnotetext{
${ }^{22}$ Crépon, Duguet, and Mairesse (1998) acknowledge that the main drawback of their study in this respect is the cross-sectional nature of their data.
} 
Our identification strategy relies on using measures of whether management consider specific business strategies of the workplace to be important as additional determinants of innovation performance. Among 15 possible business strategies, we identify two that might be more closely related to innovation performance, as follows:

- Developing new production/operating techniques.

- Improving product/service quality.

For each of these strategies, we construct a dichotomous variable equal to one if the strategy was deemed important, very important or crucial and 0 if it was deemed not important or slightly important. Note that the survey questions that were related to strategy were only included in the questionnaire in odd years; therefore we use the sample taken from years 1999, 2001, 2003 and 2005.

The results of the estimation of the system are presented in Table 11. The first column presents the coefficient estimates for the production function, and the second column presents the coefficients for process innovation. The estimates for the elasticity of labor in the productivity equation are comparable to those previously obtained with this type of data, providing some confidence that our estimation strategy deals appropriately with non-observed capital stocks. As with previous research, the current results demonstrate that the impact of firm-sponsored classroom training on productivity is greater than that of on-the-job training.

Turning to the innovation equation, we find that both business strategies are positively associated with innovation performance and we easily reject the null hypothesis of no effects. ${ }^{23}$ More importantly, improved process innovation continues to have a statistically significant positive impact on productivity, yielding a $2.4 \%$ productivity gain. Turning to coefficient estimates for firm-sponsored training, the results confirm that both classroom and on-the-job training increase innovation in a similar manner. Taken together, these results highlight that on-the-job training can have an impact on productivity through process innovation.

\section{Conclusion}

In this article, we estimate the impact of firm-sponsored training on firm-level innovation performance utilizing longitudinal linked employer-employee Canadian data from WES 1999-2006. We find that both firm-sponsored classroom and on-the-job training have a positive impact on innovation performance with on-the-job training

$\overline{{ }^{23} F(2,13209)}=145.90$ and $\operatorname{Prob}>F=0.0000$. Additionally, we cannot reject the null hypothesis that the over-identifying restrictions are valid: the Sargan statistic is 0.774 with an associated Chisq(1) P-value of 0.3791 
playing a role that is as important as classroom training in explaining differences in innovation output.

The important role for on-the-job training in innovation performance is in contrast to its weak direct impact on productivity. When jointly estimating the determinants of innovation and the impact of innovation and training on productivity, we further find that on-the-job training has a significant indirect impact on productivity, primarily through improved process innovation. This result demonstrates that a workplace that aims to improve productivity should not underplay the role of on-the-job training.

Future research should focus on determining the particular reasons why on-the-job training has different direct impacts on productivity and innovation. It would also be interesting to investigate whether different subjects of training have different impacts on innovation. Some of the subjects of training that have a large impact on productivity (such as sales and marketing training, and managerial/supervisory training) might be less likely to have a large impact on innovation performance.

Finally, it would also be interesting to investigate possible complementarities between human capital investments and other firm-level investment decisions in physical or organizational capital. There is a lack of results on whether complementarities that drives productivity growth might also drive innovation (Bresnahan, Brynjolfsson, and Hitt (2002)). 


\section{REFERENCES}

Abowd, J. M. and F. Kramarz (1999). The analysis of labor markets using matched employer-employee data. In O. Ashenfelter and D. Card (Eds.), Handbook of Labor Economics, vol 3B, Chapter 40, pp. 2629-2710. Elsevier Science North Holland.

Aghion, P., N. Bloom, R. Blundell, R. Griffith, and P. Howitt (2005). Competition and innovation: An inverted-U relationship. The Quarterly Journal of Economics 120(2), 701-728.

Aghion, P., L. Boustan, C. Hoxby, and J. Vandenbussche (2009). The causal impact of education on economic growth: Evidence from the United States. Brooking Papers on Economic Activity Conference Draft.

Aghion, P. and P. Howitt (2009, January). The Economics of Growth, Volume 1 of MIT Press Books. The MIT Press.

Arellano, M. and S. Bond (1991). Some tests of specification for panel data: Monte Carlo evidence and an application to employment equations. Review of Economic Studies 58, 277-297.

Baldwin, J. R. and J. Johnson (1995). Human Capital Development and Innovation: The Case of Training in Small and Medium Sized Firms. Statistics Canada Analytical Studies Branch Research Paper Series Working Paper no. 995074e.

Ballot, G., F. Fakhfakh, and E. Taymaz (2001). Firm's human capital, R\&D and performance: A study on French and Swedish firms. Labour Economics 8(4), $443-462$.

Baltagi, B. H. (2013). Econometric Analysis of Panel Data, Fourth Edition. John Wiley \& Sons.

Barrett, A. and P. O'Connell (2001). Does training generally work? The return to in-company training. Industrial and Labor Relations Review 54(3), 647-663.

Bauernschuster, S., O. Falck, and S. Heblich (2009). Training and innovation. Journal of Human Capital 3(4), 323-353.

Becheikh, N., R. Landry, and N. Amara (2006). Lessons from innovation empirical studies in the manufacturing sector: A systematic review of the literature from 1993-2003. Technovation 26(5).

Beugelsdijk, S. (2008). Strategic human resource practices and product innovation. Organization Studies 28, 821-847.

Black, S. and L. Lynch (1996). Human-capital investments and productivity. American Economic Review Papers and Proceedings 82(2), 263-267. 
Blundell, R. and S. Bond (2000). GMM estimation with persistent panel data: An application to production functions. Econometric Reviews 19(3), 321-340.

Bresnahan, T. F., E. Brynjolfsson, and L. M. Hitt (2002). Information technology, workplace organization and the demand for skilled labor: Firm level evidence. Quarterly Journal of Economics 117(1), 339-376.

Brunello, G. and M. De Paola (2008, February). Training and economic density: Some evidence form Italian provinces. Labour Economics 15(1), 118-140.

Crépon, B., E. Duguet, and J. Mairesse (1998). Research investment, innovation and productivity: An econometric analysis at the firm level. Economics of Innovation and New Technology 7(2), 115-158.

Dostie, B. (2013). Estimating the returns to firm-sponsored on-the-job and classroom training. Journal of Human Capital 7(2), 161-189.

Gallié, E.-P. and D. Legros (2012). Firms' human capital, R\&D and innovation: a study on French firms. Empirical Economics 43(2), 581-596.

Gonzàlez, X., D. Miles-Touya, and C. Pazò (2012). RED, Worker Training, and Innovation: Firm-level evidence. Working Paper \#1203, Universidade de Vigo, Departamento de Economìa Aplicada.

Hall, B. H. (2011). Innovation and Productivity. NBER Working Paper \# 17178.

Legros, D. and F. Galia (2012, October). Are innovation and R\&D the only sources of firms' knowledge that increase productivity? An empirical investigation of French manufacturing firms. Journal of Productivity Analysis 38(2), 167-181.

Lynch, K. and M. Sheikh (2011, September). Innovation dividend = stronger productivity growth. Policy Options.

Mairesse, J., B. Crépon, and E. Duguet (2000). Mesurer le rendement de l'innovation. Économie et Statistique 334(1), 65-78.

Michie, J. and M. Sheehan (2003). Labour market deregulation, 'flexibility' and innovation. British Journal of Industrial Relations 27(1), 123-143.

Mohnen, P. and B. H. Hall (2013, Spring). Innovation and Productivity: An Update. Eurasian Business Review 3(1), 47-65.

Organization for Economic Co-operation and Development (OECD) (2005). The Oslo Manual. Paris, 3rd Edition.

Parrotta, P., D. Pozzoli, and M. Pytlikova (2014). The nexus between labor diversity and firm's innovation. Journal of Population Economics 27(2), 303-364.

Pischke, J.-S. (2005). Comments on "Workplace training in Europe" by Bassanini et al. fRDB Conference Paper on Education and Training in Europe - London School of Economics. 
Rao, S., J. Tang, and W. Wang (2002). The Importance of Skills for Innovation and Productivity. International Productivity Monitor 4, 15-26.

Spulber, D. F. (2013). How do competitive pressures affect incentives to innovate when there is a market for inventions? Journal of Political Economy 121(6), 1007 - 1054 .

Statistics Canada (2004). Guide to the Analysis of the Workplace and Employee Survey. Statistics Canada, Labour Statistics Division, Catalogue no. 71-221-GIE.

Statistics Canada (2012). CANSIM (Tables 358-0268 to 358-0270). http://www5.statcan.gc.ca/cansim/home-accueil?lang=eng (accessed June 16th 2014).

Stoyanov, A. and N. Zubanov (2012). Productivity spillovers across firms through worker mobility. American Economic Journal: Applied Economics 4(2), 168-98.

The Expert Panel on Business Innovation (2009). Innovation and Business Strategy: Why Canada Falls Short. Council of Canadian Academies.

Walsworth, S. and A. Verma (2007). Globalization, human resource practices and innovation: Recent evidence from the Canadian workplace and employee survey. Industrial Relations: A Journal of Economy and Society 46(2), 222-240.

Zeytinoglu, I. and G. Cooke (2009). On-the-job training in Canada: Associations with new information technology, innovation introduced and competition experienced by the workplace. Journal of Industrial Relations 51(1), 95-112.

Zwick, T. (2005). Continuing vocational training forms and establishment productivity in Germany. German Economic Review 6(2), 155-184. 
Appendix A. TABles 
TABle 1. Survey Design

\begin{tabular}{ccc}
\hline \hline Year & Workplaces & Workers \\
\hline 1999 & 6,322 & 23,540 \\
2000 & 6,068 & 20,167 \\
2001 & 6,207 & 20,352 \\
2002 & 5,818 & 16,813 \\
2003 & 6,565 & 20,834 \\
2004 & 6,159 & 16,804 \\
2005 & 6,693 & 24,197 \\
2006 & 6,312 &. \\
\hline \hline
\end{tabular}

Note. Workers were not sampled in 2006. 
TABLE 2. Proportion of workplaces reporting innovation

\begin{tabular}{lcccccccc}
\hline \hline & 1999 & 2000 & 2001 & 2002 & 2003 & 2004 & 2005 & 2006 \\
\hline New products & 0.33 & 0.26 & 0.29 & 0.19 & 0.27 & 0.25 & 0.31 & 0.27 \\
New process & 0.24 & 0.19 & 0.21 & 0.12 & 0.19 & 0.16 & 0.20 & 0.17 \\
Improved products & 0.38 & 0.29 & 0.35 & 0.24 & 0.33 & 0.30 & 0.38 & 0.32 \\
Improved process & 0.29 & 0.23 & 0.24 & 0.17 & 0.25 & 0.22 & 0.26 & 0.22 \\
\hline \# workplaces & 5,462 & 5,236 & 5,362 & 5,015 & 5,708 & 5,329 & 5,860 & 5,504 \\
\hline \hline
\end{tabular}

Note. Source: WES 1999-2006. Total number of observations: 43,476. 


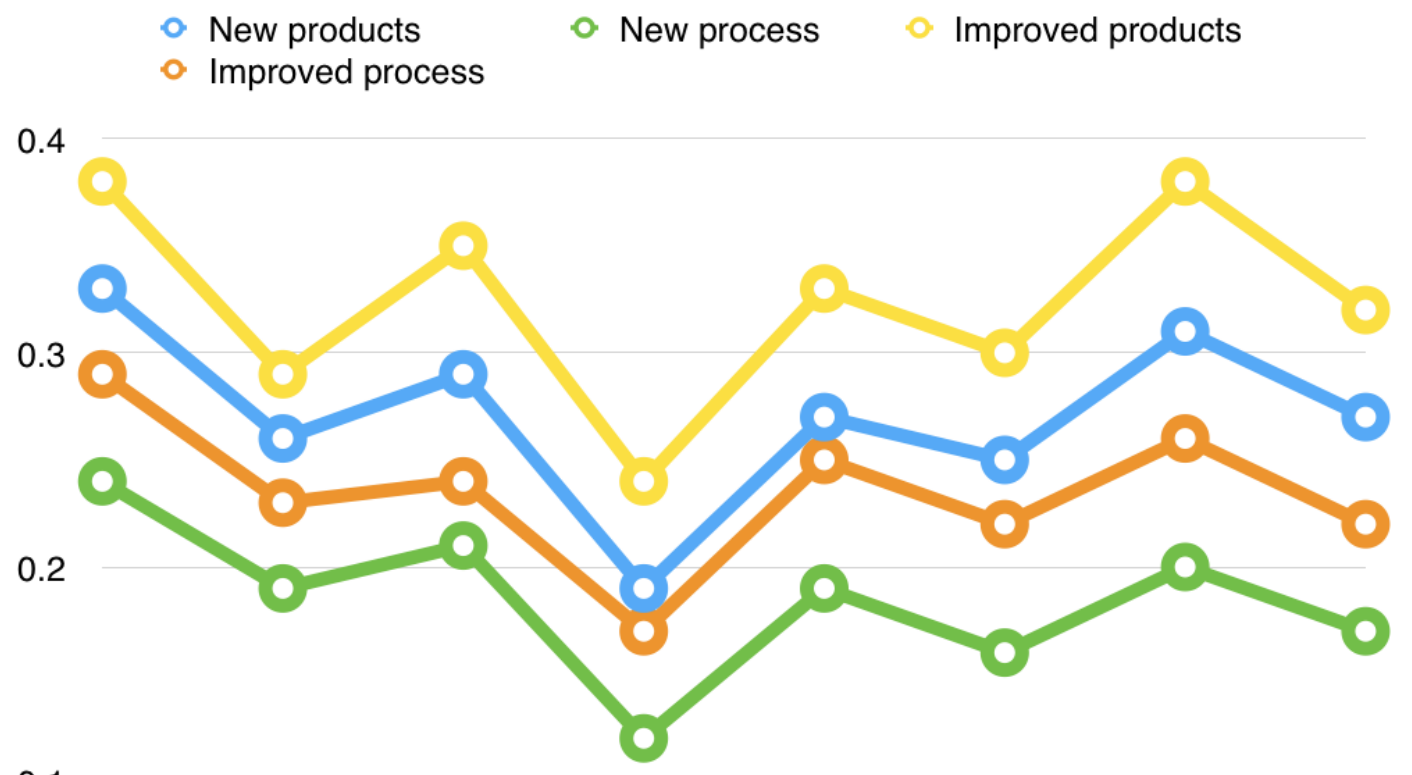

0.1

$\begin{array}{llllllll}0 & 2000 & 2001 & 2002 & 2003 & 2004 & 2005 & 2006\end{array}$

FiguRe 1. Proportion of workplaces reporting innovation 
TABLE 3. Percentage of workplaces reporting innovation depending on training status

\begin{tabular}{lccccc}
\hline \hline & & \multicolumn{2}{c}{$\begin{array}{c}\text { Offers } \\
\text { classroom } \\
\text { training }\end{array}$} & \multicolumn{2}{c}{$\begin{array}{c}\text { Offers } \\
\text { on-the-job } \\
\text { training }\end{array}$} \\
\cline { 2 - 6 } & All & YES & NO & YES & NO \\
\hline New products & 0.27 & 0.39 & 0.22 & 0.37 & 0.19 \\
New process & 0.19 & 0.31 & 0.13 & 0.28 & 0.11 \\
Improved products & 0.32 & 0.46 & 0.26 & 0.43 & 0.23 \\
Improved process & 0.24 & 0.38 & 0.17 & 0.35 & 0.14 \\
\hline \hline
\end{tabular}

Note. Source: WES 1999-2006. Total number of observations: 43,476 . 
all $\quad$ Offers classroom training Does not offer classroom training

0.5

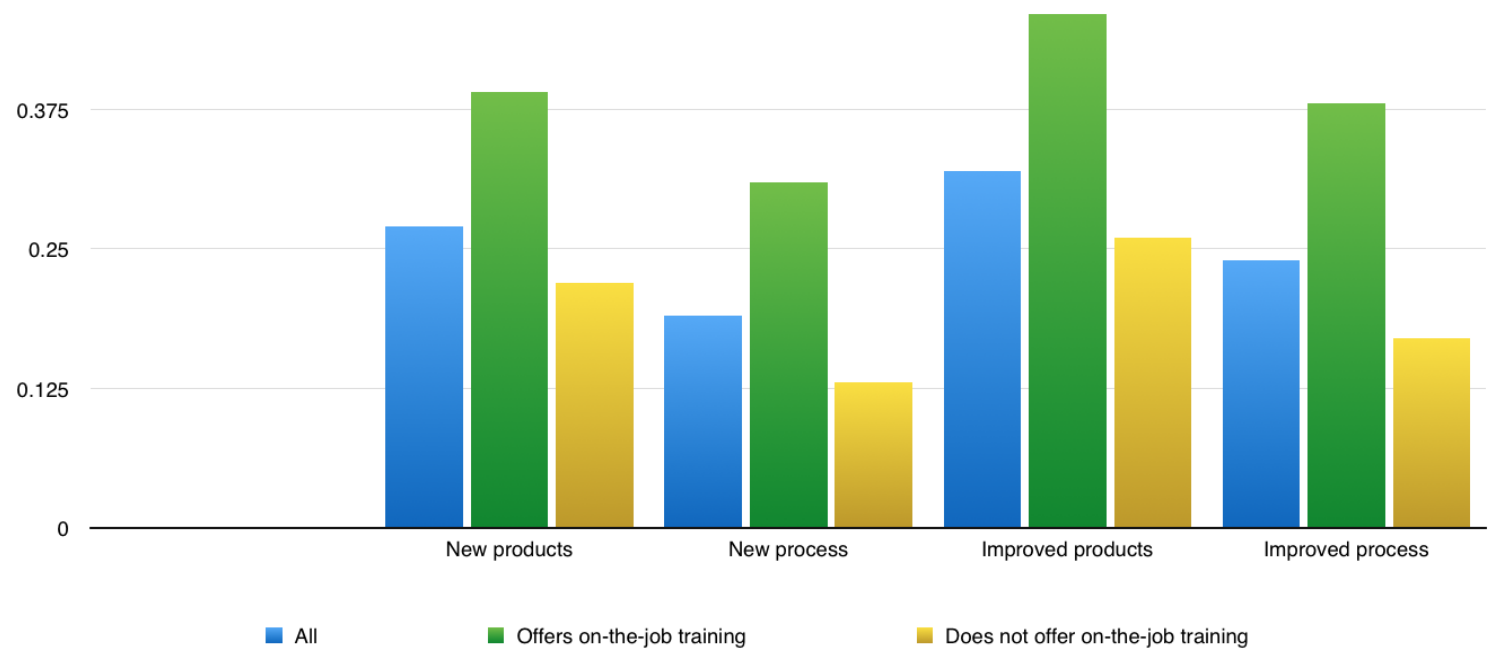

0.5

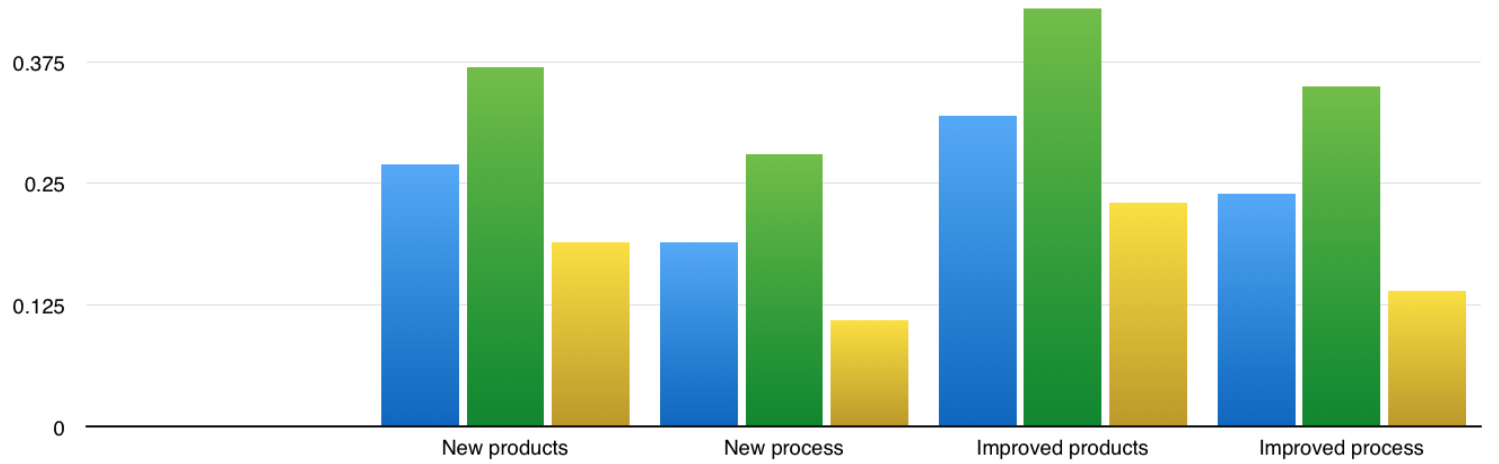

Figure 2. Percentage of workplaces reporting innovation depending on training status 
TABLE 4. Average training intensities for innovating and non-innovating workplaces

\begin{tabular}{lccccc}
\hline \hline & \multicolumn{2}{c}{$\begin{array}{c}\text { New } \\
\text { products }\end{array}$} & \multicolumn{2}{c}{$\begin{array}{c}\text { Improved } \\
\text { products }\end{array}$} \\
\cline { 2 - 6 } & YES & NO & YES & NO & Total \\
\hline Classroom training intensity & 0.28 & 0.16 & 0.27 & 0.15 & 0.19 \\
On-the-job training intensity & 0.42 & 0.24 & 0.40 & 0.23 & 0.29 \\
\hline & \multicolumn{2}{c}{ New } & \multicolumn{4}{c}{ Improved } \\
& process & process & \\
\cline { 2 - 6 } & YES & NO & YES & NO & Total \\
\hline Classroom training intensity & 0.33 & 0.16 & 0.32 & 0.15 & 0.19 \\
On-the-job training intensity & 0.47 & 0.25 & 0.46 & 0.24 & 0.29 \\
\hline \hline
\end{tabular}

Note. Source: WES 1999-2006. Total number of observations: 43,476. 
TABLE 5. Linear probability model: OLS coefficient estimates

\begin{tabular}{lcccc}
\hline \hline & \multicolumn{2}{c}{ Product } & \multicolumn{2}{c}{ Process } \\
\cline { 2 - 5 } & New & Improved & New & Improved \\
\hline Classroom training intensity & $0.131^{* * *}$ & $0.137^{* * *}$ & $0.125^{* * *}$ & $0.137^{* *}$ \\
& $(0.003)$ & $(0.010)$ & $(0.006)$ & $(0.019)$ \\
On-the-job training intensity & $0.164^{* * *}$ & $0.177^{* * *}$ & $0.159^{* * *}$ & $0.191^{* * *}$ \\
& $(0.005)$ & $(0.002)$ & $(0.008)$ & $(0.014)$ \\
Workforce characteristics & & & & \\
Prop. of empl. using a computer & $0.093^{* *}$ & $0.091^{* *}$ & $0.070^{* * *}$ & $0.088^{* * *}$ \\
& $(0.013)$ & $(0.012)$ & $(0.002)$ & $(0.005)$ \\
Prop. of empl. covered by a CBA & $0.020^{* * *}$ & 0.025 & -0.003 & 0.022 \\
& $(0.002)$ & $(0.020)$ & $(0.006)$ & $(0.010)$ \\
Prop. of managers & $0.044^{* * *}$ & 0.024 & 0.032 & 0.024 \\
& $(0.004)$ & $(0.010)$ & $(0.021)$ & $(0.015)$ \\
Firm Size & & & & \\
1-19 employees & - & - & - & - \\
20-99 employees & - & - & - & - \\
& $0.077^{* * *}$ & $0.099^{* *}$ & $0.086^{* * *}$ & $0.109^{* * *}$ \\
100-499 employees & $(0.007)$ & $(0.012)$ & $(0.007)$ & $(0.004)$ \\
& $0.093^{* * *}$ & $0.133^{* * *}$ & $0.186^{* * *}$ & $0.190^{* * *}$ \\
500 employees and more & $(0.007)$ & $(0.010)$ & $(0.016)$ & $(0.009)$ \\
& $0.150^{* *}$ & $0.164^{* *}$ & $0.233^{* *}$ & $0.239^{* * *}$ \\
Constant & $(0.034)$ & $(0.036)$ & $(0.050)$ & $(0.017)$ \\
& 0.031 & $0.087^{* * *}$ & 0.040 & $0.071^{*}$ \\
\# observations & $(0.016)$ & $(0.005)$ & $(0.018)$ & $(0.018)$ \\
R-squared & 43476 & 43476 & 43476 & 43476 \\
\hline \hline
\end{tabular}

Note. Bootstrapped standard errors in parentheses. ${ }^{*}$ significant at $10 \% ;{ }^{* *}$ significant at $5 \%$; ${ }^{* *}$ significant at $1 \%$. Includes year (8) and industry dummies (14). 
TABLE 6. Linear probability model: OLS coefficient estimates with turnover

\begin{tabular}{|c|c|c|c|c|}
\hline & \multicolumn{2}{|c|}{ Product } & \multicolumn{2}{|c|}{ Process } \\
\hline & New & Improved & New & Improved \\
\hline Classroom training intensity & $0.132^{* *}$ & $0.130^{* * *}$ & $0.121^{* * *}$ & $0.124^{* * *}$ \\
\hline On-the-job training intensity & $\begin{array}{c}(0.017) \\
0.180^{* * *}\end{array}$ & $\begin{array}{c}(0.008) \\
0.165 * * *\end{array}$ & $\begin{array}{c}(0.005) \\
0.151^{* * *}\end{array}$ & $\begin{array}{c}(0.002) \\
0.154^{* * *} \\
(0.005)\end{array}$ \\
\hline Workforce characteristics & & & & \\
\hline Prop. Of empl. Using a computer & $\begin{array}{c}0.089^{* * *} \\
(0.005)\end{array}$ & $\begin{array}{c}0.090^{* *} \\
(0.012)\end{array}$ & $\begin{array}{c}0.070^{* * *} \\
(0.002)\end{array}$ & $\begin{array}{c}0.094^{* *} \\
(0.012)\end{array}$ \\
\hline Prop. Of Empl. Covered by a CBA & $\begin{array}{c}0.018 \\
(0.009)\end{array}$ & $\begin{array}{c}0.020 \\
(0.017)\end{array}$ & $\begin{array}{l}-0.006 \\
(0.005)\end{array}$ & $\begin{array}{c}0.016^{* * *} \\
(0.001)\end{array}$ \\
\hline Prop. Of managers & $\begin{array}{c}0.031 \\
(0.014)\end{array}$ & $\begin{array}{l}0.034^{*} \\
(0.010)\end{array}$ & $\begin{array}{c}0.037 \\
(0.020)\end{array}$ & $\begin{array}{c}0.053^{* * *} \\
(0.003)\end{array}$ \\
\hline Firm Size & & & & \\
\hline 1-19 employees & $\begin{array}{l}- \\
-\end{array}$ & - & - & - \\
\hline 20-99 employees & $\begin{array}{c}0.097^{* * *} \\
(0.004)\end{array}$ & $\begin{array}{c}0.084^{* *} \\
(0.012)\end{array}$ & $\begin{array}{c}0.077^{* * * *} \\
(0.006)\end{array}$ & $\begin{array}{c}0.064^{* *} \\
(0.007)\end{array}$ \\
\hline 100-499 employees & $\begin{array}{c}0.178^{* * *} \\
(0.008)\end{array}$ & $\begin{array}{c}0.118^{* * *} \\
(0.009)\end{array}$ & $\begin{array}{c}0.177^{* * *} \\
(0.015)\end{array}$ & $\begin{array}{c}0.081^{* * *} \\
(0.007)\end{array}$ \\
\hline 500 employees and more & $\begin{array}{c}0.227^{* * *} \\
(0.016)\end{array}$ & $\begin{array}{c}0.149^{*} \\
(0.038)\end{array}$ & $\begin{array}{c}0.224^{* *} \\
(0.052)\end{array}$ & $\begin{array}{l}0.136^{*} \\
(0.036)\end{array}$ \\
\hline Turnover & & & & \\
\hline Inflow rate & $\begin{array}{c}0.021^{* * *} \\
(0.000)\end{array}$ & $\begin{array}{c}0.023^{* * *} \\
(0.000)\end{array}$ & $\begin{array}{c}0.015^{* *} \\
(0.002)\end{array}$ & $\begin{array}{c}0.023^{* * *} \\
(0.001)\end{array}$ \\
\hline Outflow rate & $\begin{array}{c}-0.017^{* *} \\
(0.004)\end{array}$ & $\begin{array}{c}-0.023^{* *} \\
(0.004)\end{array}$ & $\begin{array}{l}-0.014 \\
(0.005)\end{array}$ & $\begin{array}{c}-0.022^{*} \\
(0.006)\end{array}$ \\
\hline Competitive pressures & & & & \\
\hline No direct competitor & $\begin{array}{l}- \\
-\end{array}$ & $\begin{array}{l}- \\
-\end{array}$ & $\begin{array}{l}- \\
-\end{array}$ & $\begin{array}{l}- \\
-\end{array}$ \\
\hline 1-5 competitors & $\begin{array}{c}0.046^{* * *} \\
(0.004)\end{array}$ & $\begin{array}{c}0.133^{* * *} \\
(0.011)\end{array}$ & $\begin{array}{c}0.041^{* *} \\
(0.006)\end{array}$ & $\begin{array}{c}0.099^{* * *} \\
(0.006)\end{array}$ \\
\hline 6-20 competitors & $\begin{array}{c}0.097^{* * *} \\
(0.008)\end{array}$ & $\begin{array}{c}0.147^{* * * *} \\
(0.008)\end{array}$ & $\begin{array}{c}0.069^{* *} \\
(0.010)\end{array}$ & $\begin{array}{c}0.107^{* *} \\
(0.021)\end{array}$ \\
\hline 20 competitors or more & $\begin{array}{c}0.076^{* * * *} \\
(0.007)\end{array}$ & $\begin{array}{c}0.115^{* * *} \\
(0.006)\end{array}$ & $\begin{array}{c}0.067 * * * \\
(0.005)\end{array}$ & $\begin{array}{c}0.073^{* *} \\
(0.013)\end{array}$ \\
\hline Constant & $\begin{array}{c}0.031 \\
(0.015)\end{array}$ & $\begin{array}{c}0.003 \\
(0.009)\end{array}$ & $\begin{array}{c}0.006 \\
(0.017)\end{array}$ & $\begin{array}{c}-0.024 \\
(0.011)\end{array}$ \\
\hline Observations & 43476 & 43476 & 43476 & 43476 \\
\hline R-squared & 0.12 & 0.10 & 0.11 & 0.11 \\
\hline
\end{tabular}

Note. Bootstrapped standard errors in parentheses. ${ }^{*}$ significant at $10 \% ;{ }^{* *}$ significant at $5 \%$; ** significant at $1 \%$. Includes year (8) and industry dummies (14). 
TABLE 7. Linear probability model: FE coefficient estimates

\begin{tabular}{lcccc}
\hline \hline & \multicolumn{2}{c}{ Product } & \multicolumn{2}{c}{ Process } \\
\cline { 2 - 5 } & New & Improved & New & Improved \\
\hline Classroom training intensity & $0.073^{* * *}$ & $0.074^{* *}$ & $0.054^{* *}$ & $0.078^{* *}$ \\
& $(0.005)$ & $(0.012)$ & $(0.007)$ & $(0.014)$ \\
On-the-job training intensity & $0.066^{* *}$ & $0.086^{* *}$ & $0.092^{* *}$ & $0.112^{* *}$ \\
& $(0.011)$ & $(0.009)$ & $(0.010)$ & $(0.012)$ \\
Workforce characteristics & & & & \\
Proportion of employees using & 0.037 & $0.036^{* *}$ & $0.034^{* * *}$ & $0.050^{* * *}$ \\
a computer & $(0.013)$ & $(0.007)$ & $(0.002)$ & $(0.002)$ \\
Proportion of employees covered & 0.006 & $0.040^{* *}$ & -0.034 & -0.006 \\
by a CBA & $(0.026)$ & $(0.008)$ & $(0.021)$ & $(0.040)$ \\
Proportion of managers & 0.028 & $0.006^{* *}$ & 0.040 & $0.036^{* *}$ \\
& $(0.015)$ & $(0.001)$ & $(0.022)$ & $(0.008)$ \\
Firm Size & & & & \\
1-19 employees & - & - & - & - \\
20-99 employees & - & - & - & - \\
100-499 employees & 0.035 & $0.028^{* *}$ & -0.016 & 0.014 \\
& $(0.019)$ & $(0.004)$ & $(0.010)$ & $(0.021)$ \\
500 employees and more & 0.064 & 0.036 & 0.059 & 0.064 \\
& $(0.039)$ & $(0.027)$ & $(0.031)$ & $(0.032)$ \\
\# observations & 0.062 & $0.061^{* *}$ & -0.001 & 0.019 \\
R-squared & $(0.032)$ & $(0.012)$ & $(0.011)$ & $(0.017)$ \\
\hline \hline
\end{tabular}

Note. Bootstrapped standard errors in parentheses. ${ }^{*}$ significant at $10 \% ;{ }^{* *}$ significant at $5 \%$; ${ }^{* *}$ significant at $1 \%$. Includes year (8) and industry dummies (14). 
TABLE 8. Linear probability model: GMM coefficient estimates

\begin{tabular}{lcccc}
\hline \hline & \multicolumn{2}{c}{ Product } & \multicolumn{2}{c}{ Process } \\
\cline { 2 - 5 } & New & Improved & New & Improved \\
\hline Classroom training intensity & $0.046^{* * *}$ & $0.071^{* * *}$ & $0.062^{* * *}$ & $0.071^{* * *}$ \\
& $(0.012)$ & $(0.013)$ & $(0.012)$ & $(0.012)$ \\
On-the-job training intensity & $0.061^{* * *}$ & $0.057^{* * *}$ & $0.081^{* * *}$ & $0.070^{* * *}$ \\
& $(0.011)$ & $(0.012)$ & $(0.011)$ & $(0.011)$ \\
\hline$\alpha$ & $0.126^{* * *}$ & $0.106^{* * *}$ & $0.126^{* * *}$ & $0.064^{* *}$ \\
& $(0.034)$ & $(0.033)$ & $(0.032)$ & $(0.031)$ \\
\hline \# observations & 27287 & 27287 & 27287 & 27287 \\
\hline \hline
\end{tabular}

Note. Bootstrapped standard errors in parentheses. ${ }^{*}$ significant at $10 \%$; $* *$ significant at $5 \%$; *** significant at $1 \%$. Includes year (8) and industry dummies (14). 
TABLE 9. Linear probability model: OLS coefficient estimates

\begin{tabular}{lcccc}
\hline \hline & \multicolumn{2}{c}{ Product } & \multicolumn{2}{c}{ Process } \\
\cline { 2 - 5 } & New & Improved & New & Improved \\
\hline Classroom training intensity & $0.130^{* * *}$ & $0.136^{* * *}$ & $0.122^{* * *}$ & $0.131^{* * *}$ \\
& $(0.021)$ & $(0.021)$ & $(0.020)$ & $(0.020)$ \\
On-the-job training intensity & $0.158^{* * *}$ & $0.172^{* * *}$ & $0.169^{* * *}$ & $0.203^{* * *}$ \\
& $(0.019)$ & $(0.019)$ & $(0.017)$ & $(0.018)$ \\
Workforce characteristics & & & & \\
Proportion of employees with & $0.047^{* * *}$ & $0.043^{* *}$ & $0.026^{*}$ & 0.021 \\
some post-secondary education & $(0.018)$ & $(0.019)$ & $(0.014)$ & $(0.015)$ \\
Proportion of employees using & $0.076^{* * *}$ & $0.083^{* * *}$ & $0.067^{* * *}$ & $0.080^{* * *}$ \\
a computer & $(0.023)$ & $(0.024)$ & $(0.018)$ & $(0.021)$ \\
Proportion of employees covered & -0.015 & 0.007 & -0.001 & 0.020 \\
by a CBA & $(0.025)$ & $(0.028)$ & $(0.023)$ & $(0.026)$ \\
Occupational structure of the workplace & & & & \\
Proportion of managers & $0.090^{* * *}$ & $0.078^{* *}$ & $0.056^{* *}$ & $0.048^{*}$ \\
& $(0.030)$ & $(0.032)$ & $(0.024)$ & $(0.026)$ \\
Proportion of professionals & $0.086^{* *}$ & $0.084^{* *}$ & $0.076^{* *}$ & 0.048 \\
& $(0.034)$ & $(0.035)$ & $(0.030)$ & $(0.032)$ \\
Proportion of marketing/sales & $0.189^{* * *}$ & $0.117^{* * *}$ & 0.011 & -0.001 \\
& $(0.039)$ & $(0.040)$ & $(0.027)$ & $(0.031)$ \\
Proportion of clerical/administrative & - & - & - & - \\
& - & - & - & - \\
Proportion of technical/trades & $0.065^{* *}$ & $0.053^{*}$ & $0.057^{* *}$ & 0.025 \\
& $(0.029)$ & $(0.031)$ & $(0.023)$ & $(0.027)$ \\
Proportion of production workers & 0.026 & 0.037 & 0.025 & 0.010 \\
& $(0.028)$ & $(0.030)$ & $(0.022)$ & $(0.026)$ \\
Proportion of others & $0.058^{*}$ & $0.076^{* *}$ & 0.030 & 0.022 \\
& $(0.032)$ & $(0.034)$ & $(0.025)$ & $(0.030)$ \\
Constant & -0.011 & 0.031 & 0.018 & $0.062^{*}$ \\
& $(0.031)$ & $(0.033)$ & $(0.028)$ & $(0.032)$ \\
\hline Observations & 31948 & 31948 & 31948 & 31948 \\
R-squared & 0.10 & 0.09 & 0.10 & 0.12 \\
\hline \hline
\end{tabular}

Note. Bootstrapped standard errors in parentheses. ${ }^{*}$ significant at $10 \% ;{ }^{* *}$ significant at $5 \%$; *** significant at $1 \%$. Includes workplace size (4), year (8) and industry dummies (14). 
TABLE 10. Coefficient estimates: production function, reduced form model

\begin{tabular}{|c|c|c|c|}
\hline & $(1)$ & $(2)$ & $(3)$ \\
\hline $\ln$ (no. employees) & $\begin{array}{c}0.972^{* * *} \\
(0.010)\end{array}$ & $\begin{array}{c}0.965^{* * *} \\
(0.011)\end{array}$ & $\begin{array}{c}0.964^{* * *} \\
(0.012)\end{array}$ \\
\hline Classroom training intensity & $\begin{array}{c}0.123^{* * *} \\
(0.023)\end{array}$ & $\begin{array}{c}0.095^{* * *} \\
(0.022)\end{array}$ & $\begin{array}{c}0.074^{* * *} \\
(0.021)\end{array}$ \\
\hline On-the-job training intensity & $\begin{array}{c}-0.032^{*} \\
(0.017)\end{array}$ & $\begin{array}{c}-0.011 \\
(0.017)\end{array}$ & $\begin{array}{c}-0.012 \\
(0.023)\end{array}$ \\
\hline Innovation ( $t$ ) & & & \\
\hline new product & $\begin{array}{c}0.005 \\
(0.035)\end{array}$ & $\begin{array}{c}0.014 \\
(0.042)\end{array}$ & $\begin{array}{c}0.018 \\
(0.042)\end{array}$ \\
\hline improved product & $\begin{array}{l}-0.042 \\
(0.034)\end{array}$ & $\begin{array}{c}-0.082^{* *} \\
(0.039)\end{array}$ & $\begin{array}{c}-0.091^{* *} \\
(0.042)\end{array}$ \\
\hline new process & $\begin{array}{l}-0.042 \\
(0.040)\end{array}$ & $\begin{array}{l}-0.053 \\
(0.045)\end{array}$ & $\begin{array}{c}-0.058 \\
(0.049)\end{array}$ \\
\hline improved process & $\begin{array}{c}0.086^{* *} \\
(0.040)\end{array}$ & $\begin{array}{c}0.105^{* *} \\
(0.043)\end{array}$ & $\begin{array}{c}0.101^{* *} \\
(0.048)\end{array}$ \\
\hline Innovation $(t-1)$ & & & \\
\hline new product & & $\begin{array}{c}0.040 \\
(0.038)\end{array}$ & $\begin{array}{c}0.074^{*} \\
(0.052)\end{array}$ \\
\hline improved product & & $\begin{array}{l}-0.045 \\
(0.039)\end{array}$ & $\begin{array}{l}-0.065 \\
(0.043)\end{array}$ \\
\hline new process & & $\begin{array}{c}-0.065 \\
(0.047)\end{array}$ & $\begin{array}{c}-0.056 \\
(0.050)\end{array}$ \\
\hline improved process & & $\begin{array}{c}0.104^{* *} \\
(0.046)\end{array}$ & $\begin{array}{c}0.113^{* *} \\
(0.043)\end{array}$ \\
\hline Innovation (t-2) & & & \\
\hline new product & & & $\begin{array}{c}0.011 \\
(0.041)\end{array}$ \\
\hline improved product & & & $\begin{array}{c}-0.069^{*} \\
(0.042)\end{array}$ \\
\hline new process & & & $\begin{array}{c}-0.049 \\
(0.054)\end{array}$ \\
\hline improved process & & & $\begin{array}{c}0.115^{* *} \\
(0.053)\end{array}$ \\
\hline Constant & $\begin{array}{c}11.018^{* * *} \\
(0.062)\end{array}$ & $\begin{array}{c}11.055^{* * *} \\
(0.076)\end{array}$ & $\begin{array}{c}10.994^{* * *} \\
(0.080)\end{array}$ \\
\hline Observations & 41563 & 32761 & 24943 \\
\hline R-squared & 0.61 & 0.62 & 0.64 \\
\hline
\end{tabular}


TABLE 11. Coefficient estimates: production function, joint model

\begin{tabular}{|c|c|c|}
\hline \multirow[b]{2}{*}{$\ln ($ no. Employees $)$} & $\log ($ value added $)$ & Improved process \\
\hline & $\begin{array}{c}0.695^{* * *} \\
(0.011)\end{array}$ & \\
\hline Classroom training intensity & $\begin{array}{c}0.093^{* * *} \\
(0.016)\end{array}$ & $\begin{array}{c}0.080^{* * *} \\
(0.010)\end{array}$ \\
\hline On-the-job training intensity & $\begin{array}{c}0.017 \\
(0.014)\end{array}$ & $\begin{array}{c}0.065^{* * *} \\
(0.010)\end{array}$ \\
\hline Improved process & $\begin{array}{c}0.024^{* *} \\
(0.010)\end{array}$ & \\
\hline Development strategy & & $\begin{array}{c}0.129^{* * *} \\
(0.007)\end{array}$ \\
\hline Improvement Strategy & & $\begin{array}{c}0.058^{* * *} * \\
(0.009)\end{array}$ \\
\hline Observations & \multicolumn{2}{|c|}{21,440} \\
\hline R-squared & 0.16 & 0.04 \\
\hline \multicolumn{3}{|c|}{$\begin{array}{l}\text { Note. Bootstrapped standard errors in parentheses. }{ }^{*} \text { significant at } 10 \% ; * * \\
\text { significant at } 5 \% ; * * * \text { significant at } 1 \% \text {. Includes workforce characteristics, } \\
\text { workplace size (4), year (8) and industry dummies (14). Development strat- } \\
\text { egy: development of new production/operating techniques. Improvement } \\
\text { strategy: improvement of product/service quality. }\end{array}$} \\
\hline
\end{tabular}

